\title{
Evaluation of Potassium Fertilizer on Yield and Yield Components of Potato under Irrigation on Nitisols in Central Highlands of Ethiopia
}

\author{
Girma Chala \\ Ethiopian Institute of Agricultural Research, Holeta Agriculture Research Centre \\ P. O. Box 2003, Addis Ababa, Ethiopia
}

\begin{abstract}
Nutrient deficiency is a major constraint for potato (Solanum tuberosum L.) production in Ethiopia. Potato response to potassium fertilizer declined with widespread deficiencies of nutrients other than $\mathrm{N}$ and $\mathrm{P}$, farmers are discouraged to apply such fertilizer recommendations. This study was, therefore, conducted for two years (20182019) on nitisols under irrigation to evaluate the response of potato to potassium (K) fertilizer rates. The treatments were five (Negative control, recommended NPS, recommended NPS, recommended NPS +3 liter $\mathrm{K} /$ ha, recommended NPS + 5 liter K/ha, recommended NPS + 7liter K/ha). The experiment was arranged in a randomized complete block design replicated four times on farmers' fields. Results revealed that potato yield responded differently to the applied potassium fertilizer rates. Applications of $100 \% \mathrm{NP}$ fertilizer with 5 liter/ha potassium fertilizer had a significant $(\mathrm{p}<0.05)$ effect on marketable tuber and total tuber yield of potato. In general application of liquid potassium fertilizer ( $100 \%$ NP fertilizer with 5 liter/ha K) indicates positive response on dray matter and specific gravity. In conclusion, based on the findings of the experiment with application of 5L/ha liquid potassium fertilizer with $100 \%$ recommended NP fertilizer are economically optimum for potato production.
\end{abstract}

Keywords: Liquid fertilizer, Nitisols, Potassium, Potato

DOI: $10.7176 / \mathrm{JNSR} / 10-12-02$

Publication date:June 30th 2020

\section{INTRODUCTION}

Potato (Solanum tuberosum L.) plays a vital role in achieving food and nutrition security due to its high yielding capacity, presence of various suitable agro-ecological zones in Ethiopia, the availability of labor for production, and market accessibility with added value for its produce [1]. Potatoes can be used for a variety of purposes such as a fresh vegetable for cooking at home, as raw material for processing into food products, food ingredients, starch and alcohol, animal feed and as seed tubers for growing the next cropping season. The demand of consumers is changing from fresh tubers to processed products and large quantities of potatoes are being processed to meet the rising demand for convenient food and snacks. The major drivers behind this trend include expanding urban populations, rising incomes, diversification of diets, and lifestyles that leave less time for preparing the fresh product for consumption [2].

In Ethiopia, in 2017/2018 cropping season, the area under potato crop was 69,610 ha with the average national yield of $13.9 \mathrm{t} \mathrm{ha}^{-1}[3]$, which is still far less than other countries such as New Zealand $\left(50.2 \mathrm{t} \mathrm{ha}^{-1}\right)$ and North America (41.2 $\left.\mathrm{t} \mathrm{ha}^{-1}\right)$. Even yield potential of potato has been reported to reach about $100 \mathrm{tha}^{-1}$ [4]. This is attributed to several factors such as poor soil fertility and agronomic practices, storage problems, low market prices at harvest, diseases and insect pests. Fresh potato tubers deteriorate quickly in tropical and subtropical environments, especially in the lowlands.

Maintaining a high yielding potential in potatoes requires soil health and fertility management. Soil health depends on physical and chemical properties and functions, organic matter and biological activity, which are fundamental to sustaining agricultural production and determine, in their complexity, soil fertility and productivity [2] [5]. Anthropogenic activities are main causes of soil fertility degradation and nutrient depletion which influence significantly food production and food security in Ethiopia [6]. Inappropriate soil fertility management is the cause of food shortage and malnutrition of huge number of people which is also associated with human health impact [7]. The requirements of crop fertilization need to be correctly estimated according to the expected yield, the potential of the variety planted and the intended use of the harvested crop [2]. Before application of fertilizers, farmers should perform, where possible, a soil test to identify soil biophysical and chemical properties. Soil tests help assess fertility and indicate deficiencies that need to be addressed. Potatoes require high fertilizer rates but low utilization efficiency [2].

Nutrient imbalance and unbalanced application of plant nutrients is the principal factor affecting yield and quality of crops. For instance, excessive application of nitrogen fertilizer reduces crop yield, increases cost of production and pollutes the environment, especially soil and ground water is acidified [8]. Crop production with suboptimal levels or without fertilizer application is the common practice in Ethiopian farmers. Although the crop requirement of potassium is higher than $\mathrm{N}$ and $\mathrm{P}$ rates [9]; [10], potato is produced without its application in most 
areas. This is because potassium is believed to be sufficient in most Ethiopian soils, and as a result information about the requirement of potassium fertilizer for potato production is scarce. However, potato is grown mainly in the highland areas of the country where severe soil fertility depletion is predominant. Achieving optimum plant nutrient applications is an essential strategy as it determines yield and varies with soil, crop and water availability to the crop for optimum yield and profit. Therefore, this field trial was conducted to determine the effect of potassium fertilizer on yield and yield components of potato.

\section{Materials and Methods Experimental Site}

The experiment was conducted in the District of Welmera, Adea Berga and Ejere West Shewa Zone of Oromia National Regional State for three consecutive cropping seasons (2018 and 2019). The experiment site is located at $09^{\circ} 03^{\prime} \mathrm{N}$ latitude and $38^{0} 30^{\prime} \mathrm{E}$ longitude, 30, 60 and 32km west of Addis Ababa respectively, at an altitude of about $2400 \mathrm{~m}$ above sea level. The mean annual rainfall of the study area was $1100 \mathrm{~mm}$ of which about $85 \%$ falls from June to September and the rest from March to May. The mean annual temperature is about $14.3^{\circ} \mathrm{c}$, with the mean maximum and minimum temperatures of $21.7^{\circ} \mathrm{c}$ and $6.9^{\circ} \mathrm{c}$ respectively (Holeta Agricultural Research Center Meteorological Report, unpublished data).

Figure 1: Maps of the study area

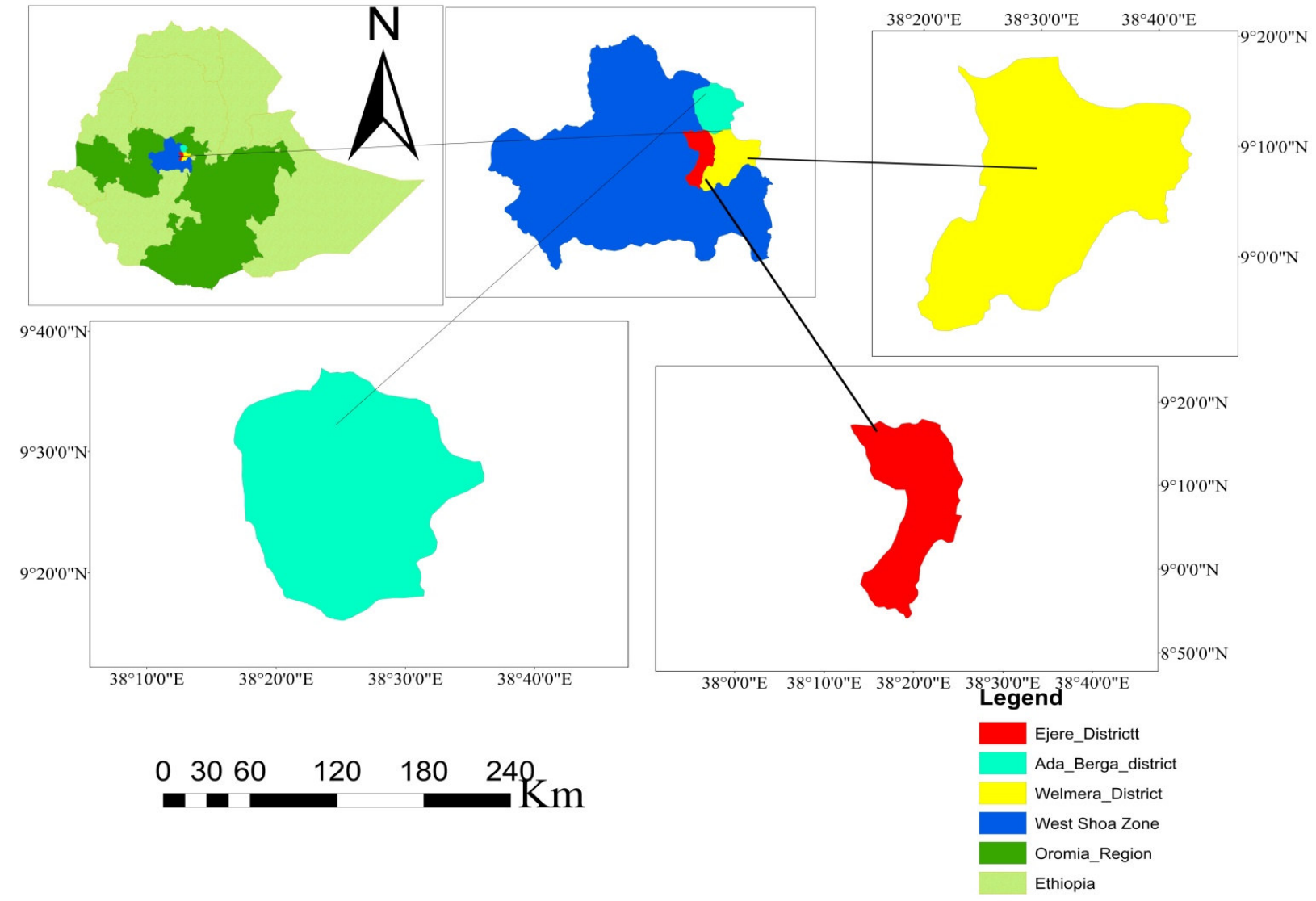

\section{Experimental procedure}

The crop was given irrigation water every two weeks, i.e., the time interval between the two successive irrigation was 14 days, and irrigation was mostly given after the depletion of $50 \%$ of soil moisture. The reason why this irrigation interval chosen was that the crop did not suffer from water stress.

The experiment included five selected treatments: 1) control; 2) recommended nitrogen, phosphorus and sulfur (NPS) rate $(75 \mathrm{~kg} / \mathrm{ha} \mathrm{N}, 39.3 \mathrm{~kg} / \mathrm{ha} \mathrm{P}$ and $16.5 \mathrm{~kg} / \mathrm{ha} \mathrm{S}) ; 3)$ recommended NPS rate + 3Liter potassium fertilizer/ha; 4) recommended NPS +5 Liter potassium fertilizer/ha; and 5) recommended NPS rate +7 Liter potassium fertilizer/ha. The experiment was set in randomized complete block design with four replications. The size of each experimental plot was $3 \mathrm{~m}$ by $4 \mathrm{~m}\left(12 \mathrm{~m}^{2}\right)$ with 4 plant rows and the spacing between rows were 75 $\mathrm{cm}$ and between plants was $30 \mathrm{~cm}$. The spacing between plots and blocks was $1.0 \mathrm{~m}$ and $1.5 \mathrm{~m}$, respectively. The recently released potato variety (Belete) was used for this study which was released in 2009 from Holetta Agricultural Research Center. Planting was done in the first week of January using irrigation.

The potassium fertilizer was applied as foliar starting one month after planting for six times and then every 
two weeks after the first application. NPS fertilizer was applied as side banding at planting time while the recommended rate of urea was applied in two splits i.e. half at planting and the other half at tillering stage. Other recommended agronomic practices such as weed, pest and disease control were applied uniformly for all treatments. The average plant height was measured from each plot of five randomly selected plants. The two central rows were harvested to determine the total and marketable yield of potato.

\section{Data management and analysis}

Days to flowering: was recorded as number of days from emergence to the time when 50 percent of the plant population in each plot produced flowers.

Plant height (cm): was measured by taking five randomly reselected plants per plot as the distance in $\mathrm{cm}$ from the soil surface to the top most growth point of aboveground at full maturity.

Leaf area index: To determine leaf area, five plants (hills) from each plot were randomly taken at 50 percent flowering. Then, three leaf samples were measured using leaf area meters. By multiplying the average leaf area with the respective leaf number of the plant, total leaf area was calculated. Leaf area index was calculated by dividing total leaf area to the respective land area occupied by plants.

Stem number: Five plants per unit area were counted at 50\% flowering.

Days to maturity: Number of days from emergence to maturity was recorded when $95 \%$ percent of the plants of different treatments were ready for harvest as indicated by the senescence of the haulms.

Marketable tuber yield (tons/ha): included marketable and healthy tubers with size categories greater than $25 \mathrm{~g}$. Unmarketable tuber yield (tons/ha): unmarketable tubers included unhealthy tubers as well as healthy tuber weighing less than $25 \mathrm{~g}$.

Total tuber yield (tons/ha): total tuber yield was recorded as the sum of all marketable and unmarketable tubers. Specific gravity of tubers $\left(\mathrm{gcm}^{-3}\right)$ : To determine the specific gravity, tubers of all size categories weighing about two kilograms were randomly taken from each plot, washed with water. The sample was then first weighed in air and then re-weighed suspended in water. Specific gravity was then determined using the following formula [11].

Specific Gravity $=\frac{\text { Weight in air }}{\text { Weight in air-Weight in water }}$.

Tuber dry matter content (\%): Five fresh tubers were randomly selected from each plot and weighed at harvest. The tubers were then sliced and dried in an oven at $65^{\circ} \mathrm{C}$ for about $72 \mathrm{hrs}$ until a constant weight is obtained. The dry weight was recorded and the dry matter percent calculated according to [12].

Dry matter $(\%)=\frac{\text { Weight of sample after drying }(g) \times 100}{\text { Initial weight of sample }(g)}$

The data were subjected to analysis of variance using the general linear model procedure (PROC GLM) of SAS statistical package version 9.3 (SAS Institute Cary, NC). The total variability for each trait was quantified using pooled analysis of variance over years using appropriate models. Means for the effects of treatments $(n=5)$ were compared using the MEANS statement with the least significant difference (LSD) test at the 5\% level.

\section{Economic analysis}

For economic evaluation, partial budget and marginal analyses were used based on the local market price of the potato total tuber yield and fertilizer cost [13]. The economic analysis was performed to investigate the economic feasibility of the treatments. The average yield was adjusted downwards $10 \%$ to reflect the difference between the experimental plot yield of and the production yield by farmers. The partial budget, dominance and marginal rate of return were calculated to determine the economic feasibility of the Final-K fertilizer for potato production under irrigation condition. The partial budget was calculated using an average yield that was adjusted downwards by $10 \%$, because we assumed that farmers would get $\sim 10 \%$ less yield than is achieved on an experimental site. The average open market price for potato (4 Ethiopian Birr (ETB) per kg) and the official prices for $\mathrm{N}$ (Urea) and $\mathrm{P}$ (NPS) were used for the analysis (urea-N: 13 Birr/kg, NPS: 15 Birr/kg, Final-K: 150 birr/Liter and labor cost for spraying Final-K fertilizer: 120 Birr/day). Thus, the total variable costs were calculated from the cost of Urea-N, NPS, Final-K and labor cost applied.

A dominance analysis was used to indicate the most economically viable options, which was done by arranging the treatments according to increasing total variable costs. The net benefit for each treatment was calculated by subtracting the total variable costs from the revenue provided by the crop. If the net benefit of a treatment was less than that of a treatment with lower total variable costs, then the treatment was considered to be dominated, and the treatment with the higher total variable costs and lower net benefit was rejected [13].

\section{RESULT AND DISCUSSION}

Soil chemical properties after harvesting

The laboratory analysis results of soil chemical properties of the trial sites after harvesting potato are presented in Table 1. The average $\mathrm{pH}$ of the experimental fields was 5.15, which was strongly acidic in reaction. The result indicated that soil organic carbon (OC), total nitrogen (TN), available phosphorus (av. P), and exchangeable 
cations were in the medium range [14]. The treatments had no significant effect on the status of soil $\mathrm{pH}$ and soil nutrients. Exchangeable potassium $(\mathrm{K})$ levels below $0.2 \mathrm{cmol}(+) / \mathrm{kg}$ suggest that a plant response to the application of $\mathrm{K}$ fertilizer is possible, particularly where heavy removal of $\mathrm{K}$ by harvesting occurs [14]. Generally, the availability of both macro-and micronutrients is reduced at $\mathrm{pH}<5.0$. In this study, the level of potassium has been found to be moderate, thus the response of potato to external K application could be unlikely. But, since potato is heavy feeder that requires more nutrients than other crops addition of plant nutrients in optimum amount is essential both to increase and sustain yield and maintain soil nutrient status at optimum level.

Table 1: Soil chemical properties of the experimental sites after harvesting

\begin{tabular}{|c|c|c|c|c|c|c|c|c|}
\hline Treatments & $\mathrm{pH}$ & $\begin{array}{l}\mathrm{OC} \\
(\%)\end{array}$ & $\begin{array}{l}\mathrm{TN} \\
(\%)\end{array}$ & $\begin{array}{l}\text { Av. P } \\
(\mathrm{mg} \mathrm{kg}- \\
\text { 1) }\end{array}$ & $\begin{array}{c}\mathrm{Ca} \\
\mathrm{meq} / 100 \mathrm{~g}\end{array}$ & $\begin{array}{c}\mathrm{Mg} \\
\mathrm{meq} / 100 \mathrm{~g}\end{array}$ & $\begin{array}{c}\mathrm{K} \\
\mathrm{meq} / 100 \mathrm{~g}\end{array}$ & $\begin{array}{c}\mathrm{Na} \\
\text { meq/100g }\end{array}$ \\
\hline Negative & 5.16 & 1.63 & 0.15 & 9.20 & 11.45 & 3.27 & 0.45 & 0.03 \\
\hline $\begin{array}{l}\text { Recommended } \\
\text { NPS }\end{array}$ & 5.14 & 1.63 & 0.16 & 11.59 & 10.41 & 2.84 & 0.45 & 0.02 \\
\hline $\begin{array}{l}\text { Recommended } \\
\text { NPS + } 3 \mathrm{Lt} \mathrm{K} / \mathrm{ha}\end{array}$ & 5.07 & 1.87 & 0.17 & 10.75 & 10.04 & 3.16 & 0.46 & 0.02 \\
\hline $\begin{array}{l}\text { Recommended } \\
\text { NPS + } 5 \mathrm{Lt} \mathrm{K} / \mathrm{ha}\end{array}$ & 5.23 & 1.99 & 0.16 & 11.06 & 10.13 & 3.04 & 0.43 & 0.02 \\
\hline $\begin{array}{l}\text { Recommended } \\
\text { NPS + } 7 \text { Lt K/ha }\end{array}$ & 5.17 & 1.99 & 0.15 & 10.92 & 11.09 & 3.07 & 0.41 & 0.02 \\
\hline Mean & 5.15 & 1.82 & 0.16 & 10.70 & 10.63 & 3.08 & 0.44 & 0.02 \\
\hline
\end{tabular}

\section{Growth Parameters of Potato}

The analysis of variance over two years revealed that the treatments significantly $(P<0.05)$ affected days to flowering, plant height, stem number, days to physiological maturity at $95 \%$ and leaf area index of potato. The highest plant height $(\sim 69 \mathrm{~cm})$, stem number (26.2) and leaf area index (5.8) were recorded at the application rate of 7 liter ha ${ }^{-1}$ liquid potassium fertilizer with recommended NPS fertilizer rate (Table 2). [15] Reported that potato plant height was significantly affected by fertilizer application and positively correlated with yield parameters, indicating that higher potato plant height contributed to higher potato yield. [16] who reported that environmental factors like nutrient status of the soil, available moisture and intercepted radiation significantly influence plant heights.

While, the highest number of days to flowering (78.8) and days to maturate (122.4) were recorded at zero rate of potassium. This result is in agreement with that of [17]who stated that days required to flowering is highly dependent on gene factors and governed by many environmental factors, nutrient, mainly temperature and light. The number of days required to flowering is one of the important parameter for potato farmers due to the fact that it enables the grower to forecast its harvesting scheme as well as the marketing plan [18]. [19]also stated that days to maturity of potato varieties varied from 90 to 120 days and the variation is accounted for by variety, soil fertility status, growing environment and cultural practices.

Table 2: The effects of potassium fertilizer on some potato growth parameters

\begin{tabular}{|c|c|c|c|c|c|}
\hline Treatments & $\begin{array}{l}\text { Days to flowering } \\
\text { at } 50 \%\end{array}$ & $\begin{array}{l}\text { Plant } \\
\text { height }(\mathrm{cm})\end{array}$ & $\begin{array}{l}\text { Stem } \\
\text { number }\end{array}$ & $\begin{array}{l}\text { Days to physiological } \\
\text { maturity at } 95 \%\end{array}$ & LAI \\
\hline Control & $78.8^{\mathrm{a}}$ & $54.8^{\mathrm{b}}$ & $16.4^{\mathrm{c}}$ & $122.4^{\mathrm{a}}$ & $3.2^{\mathrm{c}}$ \\
\hline Recommended NPS & $75.6^{b}$ & $65.9^{\mathrm{a}}$ & $22.6^{\mathrm{b}}$ & $112.6^{\mathrm{b}}$ & $4.6^{\mathrm{b}}$ \\
\hline $\begin{array}{l}\text { Recommended NPS } \\
+3 \mathrm{Lt} \mathrm{K} / \mathrm{ha}\end{array}$ & $76.4^{\mathrm{b}}$ & $66.7^{\mathrm{a}}$ & $21.5^{\mathrm{b}}$ & $114.3^{\mathrm{b}}$ & $4.8^{\mathrm{b}}$ \\
\hline $\begin{array}{l}\text { Recommended NPS } \\
+5 \mathrm{Lt} \mathrm{K} / \mathrm{ha}\end{array}$ & $75.3^{b}$ & $66.7^{\mathrm{a}}$ & $25.6^{\mathrm{b}}$ & $112.8^{\mathrm{b}}$ & $5.2^{\mathrm{ab}}$ \\
\hline $\begin{array}{l}\text { Recommended NPS } \\
+7 \mathrm{Lt} \mathrm{K} / \mathrm{ha}\end{array}$ & $74.7^{\mathrm{b}}$ & $68.9^{a}$ & $26.2^{\mathrm{b}}$ & $113.8^{\mathrm{b}}$ & $5.8^{\mathrm{a}}$ \\
\hline $\operatorname{LSD}(0.05)$ & 2.38 & 3.84 & 3.91 & 2.06 & 0.84 \\
\hline $\mathrm{CV}(\%)$ & 7.6 & 10.4 & 6.2 & 8.7 & 14.3 \\
\hline
\end{tabular}

Means followed by the same letter within a column are not significantly different at $5 \%$ level of significance. $\mathrm{LSD}=$ Least significant differences; $\mathrm{CV}=$ coefficient of variation.

\section{Yield and yield component of potato}

The analysis of variance over two years and locations revealed that the treatments significantly $(P<0.01)$ affected marketable and total tuber yields of potato. Application of potassium (Final $K$ ) in liquid form at different levels significantly $(P<0.05)$ influenced marketable and total tuber yield. Marketable tuber yield ranged from 13.7-27.5 
t/ha and total tuber yield from 23.5-37.7 t/ha. The maximum marketable tuber yield (27.5 t/ha) and total tuber yields $(37.7 \mathrm{t} / \mathrm{ha})$ of potato were recorded from the recommended NPS rate plus 5 liter ha ${ }^{-1}$ of liquid potassium fertilizer application rate, while the lowest yields of both parameters were recorded from the control treatment without application of fertilizer.

Yield and yield components of potato respond to inorganic and organic fertilizers. The application of the recommended NPS rate and the same NPS rate plus liquid K fertilizer at different levels markedly increased potato marketable yield by $86 \%$ and $89-101 \%$ compared to the recommended NPS rate and the control without any fertilizer application, respectively. However, the marketable tuber yield due to the application of the recommended NPS rate with liquid $\mathrm{K}$ fertilizer at three levels was only $2-8 \%$, compared to the recommended NPS rate, indicating that the contribution of liquid $\mathrm{K}$ fertilizer application to the yield increment of potato was insignificant (Table 3 ). On the other hand, yield and yield components of potato significantly responded to application of nitrogen and phosphorus fertilizers [15].

Table 3: Response of potassium liquid fertilizer on plant height, unmarketable, marketable tuber yield and total tuber yield of potato

\begin{tabular}{lccc}
\hline Treatments & $\begin{array}{c}\text { Unmarketable } \\
\text { yield (ton/ha) }\end{array}$ & $\begin{array}{c}\text { Marketable tuber yield } \\
\text { (ton/ha) }\end{array}$ & $\begin{array}{l}\text { Total tuber yield } \\
\text { (ton/ha) }\end{array}$ \\
\hline Control & 9.99 & $13.68 \mathrm{c}$ & $23.5 \mathrm{c}$ \\
Recommended NPS & 9.63 & $25.53 \mathrm{~b}$ & $35.16 \mathrm{~b}$ \\
Recommended NPS + 3Lt K/ha & 10.63 & $25.94 \mathrm{ab}$ & $36.56 \mathrm{ab}$ \\
Recommended NPS + 5Lt K/ha & 10.21 & $27.51 \mathrm{a}$ & $37.72 \mathrm{a}$ \\
Recommended NPS + 7Lt K/ha & 9.98 & $26.56 \mathrm{ab}$ & $36.55 \mathrm{ab}$ \\
\hline LSD $(0.05)$ & $\mathrm{NS}$ & 1.95 & 1.79 \\
CV $(\%)$ & 26.2 & 14.3 & 9.3 \\
\hline
\end{tabular}

Means followed by the same letter within a column are not significantly different at $5 \%$ level of significance. $\mathrm{LSD}=$ Least significant differences; $\mathrm{CV}=$ coefficient of variation

\section{Number of tuber categories}

The analysis of variance over two years revealed that the treatments significantly $(P<0.05)$ affected small, medium and large tuber number of potato (Table 4$)$. The highest small tuber number ( 23.01 per 5 plants) was recorded from the negative control treatment. While the maximum value of medium and large tuber numbers were recorded at the application rate of 7 liter ha ${ }^{-1}$ potassium fertilizer with recommended NPS fertilizer rate.

Table 4: Effects of potassium fertilizer on tuber number in tuber categories of potato

\begin{tabular}{lccc}
\hline Treatments & $\begin{array}{l}\text { Small tuber Number } \\
\text { /5plants }\end{array}$ & $\begin{array}{c}\text { Medium } \\
\text { Number/5 plants }\end{array}$ & $\begin{array}{c}\text { taber } \\
\text { 5plants }\end{array}$ \\
\hline Control & $23.01^{\mathrm{a}}$ & $14.1^{\mathrm{c}}$ & $4.6^{\mathrm{e}}$ \\
Recommended NPS & $13.8^{\mathrm{b}}$ & $19.6^{\mathrm{b}}$ & $14.08^{\mathrm{d}}$ \\
Recommended NPS + 3Lt K/ha & $8.8^{\mathrm{c}}$ & $24.6^{\mathrm{ab}}$ & $20.27^{\mathrm{c}}$ \\
Recommended NPS + 5Lt K/ha & $7.4^{\mathrm{c}}$ & $26.5^{\mathrm{a}}$ & $24.62^{\mathrm{b}}$ \\
Recommended NPS + 7Lt K/ha & $5.7^{\mathrm{c}}$ & $28.3^{\mathrm{a}}$ & $32.28^{\mathrm{a}}$ \\
\hline LSD $(0.05)$ & 1.22 & 2.37 & 3.16 \\
CV $(\%)$ & 9.6 & 12.4 & 16.5 \\
\hline
\end{tabular}

Means followed by the same letter within a column are not significantly different at $5 \%$ level of significance. $\mathrm{LSD}=$ Least significant differences; $\mathrm{CV}=$ coefficient of variation.

\section{Tuber Size Distribution}

The effects of potassium fertilizer were significantly $(\mathrm{P}<0.05)$ influenced yield of small, medium and large-sized tubers (Table 5). The highest yield of small-sized tuber (17.2 ton ha-1) was recorded at negative control treatment and the highest yield of medium-sized tuber (24.02 ton $\left.\mathrm{ha}^{-1}\right)$ was obtained from the application of recommended NPS with $3 \mathrm{Lt} \mathrm{ha}^{-1}$ treatments. While, the maximum value of large-sized tuber (11.33 ton ha $\left.{ }^{-1}\right)$ was recorded from recommended NPS with $5 \mathrm{Lt} \mathrm{ha}^{-1}$ of potassium fertilizer application. 
Table 5: Effects of potassium fertilizer on some yields of small, medium, and large-sized tubers of potato

\begin{tabular}{llll}
\hline Treatments & $\begin{array}{l}\text { Small-Sized tuber } \\
\text { (ton/ha) }\end{array}$ & $\begin{array}{l}\text { Medium-Sized tuber } \\
\text { (ton/ha) }\end{array}$ & $\begin{array}{l}\text { Large-Sized tuber } \\
\text { (ton/ha) }\end{array}$ \\
\hline Control & $17.2^{\mathrm{a}}$ & $5.0^{\mathrm{c}}$ & $1.3^{\mathrm{c}}$ \\
Recommended NPS & $5.18^{\mathrm{b}}$ & $22.83^{\mathrm{a}}$ & $7.15^{\mathrm{b}}$ \\
Recommended NPS + 3Lt K/ha & $4.86^{\mathrm{b}}$ & $24.02^{\mathrm{a}}$ & $7.68^{\mathrm{b}}$ \\
Recommended NPS + 5Lt K/ha & $4.25^{\mathrm{b}}$ & $21.14^{\mathrm{ab}}$ & $12.33^{\mathrm{a}}$ \\
Recommended NPS + 7Lt K/ha & $3.67^{\mathrm{c}}$ & $21.37^{\mathrm{b}}$ & $11.68 \mathrm{a}$ \\
\hline $\mathrm{LSD}(0.05)$ & 1.36 & 2.07 & 2.18 \\
$\mathrm{CV}(\%)$ & 8.4 & 12.7 & 14.2 \\
\hline
\end{tabular}

Means followed by the same letter within a column are not significantly different at $5 \%$ level of significance. $\mathrm{LSD}=$ Least significant differences; $\mathrm{CV}=$ coefficient of variation.

\section{Quality parameters}

The analysis of variance revealed that the treatment effects were significant for and specific gravity potato tuber dry matter. The highest tuber dry matter of $23.42 \%$ and specific gravity of 1.48 were recorded at the recommended NPS rate plus 5 liter ha ${ }^{-1}$ liquid $\mathrm{K}$ fertilizer rate (Table 6). This implies that specific gravity is one of the most important traits in potato crop that may provide a faster and easier measure of dry matter content [20]. This is consistent with [21] who reported that the positive correlation between specific gravity and tuber dry matter content signifies that specific gravity is a true indicator of the amount of dry matter of tubers. Potassium is the nutrient taken up by potato in higher amount; the nutritive values of potato tubers were significantly affected by potassium application [22]. Both the $\mathrm{N}$ and $\mathrm{P}$ content of potato tubers increases as the $\mathrm{K}$ application rate increases.

Table 6: Response of potassium liquid fertilizer on some potato tuber quality parameters

\begin{tabular}{lcc}
\hline Treatments & Dry mater $(\%)$ & Specific gravity \\
\hline Control & $22.36 \mathrm{c}$ & $1.33 \mathrm{c}$ \\
Recommended NPS & $22.95 \mathrm{~b}$ & $1.41 \mathrm{~b}$ \\
Recommended NPS + 3Lt K/ha & $23.18 \mathrm{ab}$ & $1.40 \mathrm{~b}$ \\
Recommended NPS + 5Lt K/ha & $23.42 \mathrm{a}$ & $1.48 \mathrm{a}$ \\
Recommended NPS + 7Lt K/ha & $23.38 \mathrm{a}$ & $1.47 \mathrm{a}$ \\
\hline LSD $(0.05)$ & 0.33 & 0.054 \\
CV $(\%)$ & 2.49 & 6.62 \\
\hline
\end{tabular}

Means followed by the same letter within a column are not significantly different at $5 \%$ level of significance. $\mathrm{LSD}=$ Least significant differences; $\mathrm{CV}=$ coefficient of variation .

\section{Economic analysis}

As it is indicated in (Table 7) the net farm benefit was calculated taking possible field variable costs and all benefits (total tuber yield). Application of final liquid $\mathrm{K}$ fertilizer at 5L/ha with $100 \%$ recommended NPS fertilizer resulted in the highest net benefit (129117birr) and marginal rate of return (1292\%). Based on the economical recommendation of [13] which stated that farmers should be willing to change from one treatment to another if the marginal rate of return of that change is greater than the minimum acceptable rate of return. Hence, use of Final-K liquid fertilizer at 5L/ha rate with $100 \%$ recommended NPS fertilizer would be desirable for potato producers in the study areas under irrigation condition.

Table 7: Final $\mathrm{K}$ fertilizer effect on partial budget and marginal rate of return for potato production.

\begin{tabular}{|c|c|c|c|c|c|c|c|c|c|c|c|c|}
\hline Testaments & $\begin{array}{l}\text { NPS } \\
(\mathrm{kg} / \mathrm{ha})\end{array}$ & $\begin{array}{l}\text { Urea } \\
(\mathrm{kg} / \mathrm{ha})\end{array}$ & $\begin{array}{l}\text { Mean } \\
\text { GY } \\
(\mathrm{kg} / \mathrm{ha})\end{array}$ & $\begin{array}{l}\text { Adj GY } \\
\text { (kg/ha) }\end{array}$ & $\begin{array}{l}\text { Gross } \\
\text { benefit } \\
\text { (ETB/ha) }\end{array}$ & $\begin{array}{l}\text { NPS } \\
\text { (cost) }\end{array}$ & $\begin{array}{l}\text { Urea } \\
(\operatorname{cost})\end{array}$ & $\begin{array}{l}\text { Sprayer } \\
\text { cost }\end{array}$ & $\begin{array}{l}\text { Final } \\
-K\end{array}$ & $\begin{array}{l}\text { Total } \\
\text { cost } \\
\text { (ETB/ha) }\end{array}$ & $\begin{array}{l}\text { Net } \\
\text { benefit } \\
\text { (ETB/ha) }\end{array}$ & $\begin{array}{l}\text { MRR } \\
(\%)\end{array}$ \\
\hline Negative & 0 & 0 & 23500 & 21150 & 84600 & 0 & 0 & 0 & 0 & 0 & 84600 & \\
\hline $\begin{array}{l}\text { Rec NPS } \\
\text { Rec NPS + 3Lt }\end{array}$ & 236 & 165 & 35160 & 31644 & 126576 & 3540 & 2145 & 0 & 0 & 5685 & 120891 & 638.4 \\
\hline $\begin{array}{l}\mathrm{K} / \mathrm{ha} \\
\mathrm{Rec} \mathrm{NPS}+5 \mathrm{Lt}\end{array}$ & 236 & 165 & 36560 & 32904 & 131616 & 3540 & 2145 & 240 & 450 & 6375 & 125241 & 630.5 \\
\hline $\begin{array}{l}\mathrm{K} / \mathrm{ha} \\
\mathrm{Rec} \mathrm{NPS}+7 \mathrm{Lt}\end{array}$ & 236 & 165 & 37720 & 33948 & 135792 & 3540 & 2145 & 240 & 750 & 6675 & 129117 & 1292 \\
\hline $\mathrm{K} / \mathrm{ha}$ & 236 & 165 & 36550 & 32895 & 131580 & 3540 & 2145 & 240 & 1050 & 6975 & 1246.05D & \\
\hline
\end{tabular}

\section{CONCLUSION}

Use of potassium fertilizer at the appropriate rate with other plant nutrients plays a key role in resisting plant diseases, improving the yield and quality of potato. Potato plants well supplied with $\mathrm{K}$ have also been found to withstand frost better than plants low in potassium. In this study, application of liquid potassium fertilizer with recommended NPS fertilizer rate significantly improved the growth, yield and quality of potato on Nitisols of central highlands of Ethiopia. Therefore, application of Final-K liquid fertilizer at 5 Liter ha ${ }^{-1}$ with $100 \%$ recommended NPS fertilizer rate is recommended for potato production in the study area and other similar areas 
under irrigation condition.

\section{ACKNOWLEDGMENTS}

We would like to thank the Victus Trade Corp Company for the provision of the products as well as financial support and I would like to express my appreciation also to Mr. Haile Beza, Mr. Beyene Ofa, Mr. Tesfaye Negash, Mr. Hailamariam Makonin, Mrs. Kessach Birhanu, and Mrs. Tigist Feyisa for their technical assistance during the execution of the experiments under field condition. Appreciation is also due for the services of the analytical soil laboratory of Holeta Agricultural Research Center of EIAR.

\section{REFERENCES}

1 Hirpa, A., Meuwissen, M., Lommen, W., Lansink, A. O., Tsegaye, A., and Struik, P. (2016). Improving seed potato quality in Ethiopia: a value chain perspective. In "Quality and innovation in food chains: Lessons and insights from Africa", pp. 84-122. Wageningen Academic Publishers.

2 Lutaladio, N., Ortiz, O., and Caldiz, D. (2009). "Sustainable potato production. Guidelines for developing countries," Food and Agriculture Organization.

3 CSA (2018). Report on area and production of major crops. Agricultural Sample Survey 2017/18, Central Statistical Agency (CSA). Volume 1. Addis Ababa, Ethiopia

4 Grewal, J. S., Saini, S. S., and Sharma, R. C. (1992). "Agrotechniques for intensive potato cultivation in India," Indian Council of Agricultural Research: Publications and Information Divisions, New Delhi, India.

5 Nabhan, H., Mashali, A., and Mermut, A. (1997). Integrated soil management for sustainable agriculture and food security in Southern and East Africa. Proceedings of the Expert Consultation, Harare, Zimbabwe, 8-12.

6 Agegnehu, G., and Amede, T. (2017). Integrated soil fertility and plant nutrient management in tropical agroecosystems: A review. Pedosphere 27, 662-680.

7 Zeleke, G., Agegnehu, G., Abera, D., and Rashid, S. (2010). Fertilizer and soil fertility potential in Ethiopia: Constraints and opportunities for enhancing the system. International Food Policy Research Institute (IFPRI). pp. 63, Washington, DC, USA.

8 Alemaw, G., and Agegnehu, G. (2019). Precision Agriculture and the Need to Introduce in Ethiopia. Ethiopian Journal of Agricultural Sciences 29, 139-158.

9 Bansal, S., and Trehan, S. (2011). Effect of potassium on yield and processing quality attributes of potato. Karnataka Journal of Agricultural Sciences 24, 48-54.

10 Shunka, E., Chindi, A., Gebremedhin, W. G., Seid, E., and Tessema, L. (2017). Determination of optimum nitrogen and potassium levels for potato production in central high lands of Ethiopia. Open Agriculture 2, 189-194

11 Kleinkopf,G.E., D. T.Wester mann and M. J. Willie, 1987.Specific gravity of Russet Burbank potatoes. American Potato Journal. 64: 579-587

12 William, M.A. and G.W. Woodbury, 1968. Specific gravity dry matter relationship and reducing sugar changes affected by potato variety, production area and storage. American Potato Journal. 45(4): 119-131.

13 CIMMYT (1988). "From agronomic data to farmer recommendations: An economics training manual. Completely revised edition," CIMMYT, Mexico, D.F.

14 Hazelton, P., and Murphy, B. (2016). "Interpreting soil test results: What do all the numbers mean?," CSIRO publishing.

15 Zelalem, A., Tekalign, T., and Nigussie, D. (2009). Response of potato (Solanum tuberosum L.) to different rates of nitrogen and phosphorus fertilization on vertisols at Debre Berhan, in the central highlands of Ethiopia. African Journal of Plant Science 3, 016-024.

16 Singh, T.P. and K.B. Singh, 1973. Association of grain yield and its components in segregations of green gram. Indian J. Genetics. 33: 112-117.

17 Vreugdenhil, D., 2007. Potato biology and biotechnology advances and perspectives. Elsevier Ltd. 823p.

18 Kahalafalla, D.I., D.N. Georgakis, N.I. Stavropoulos, E.X. Nianiou, and I.A. Vezyroglou. 2001. Effect of planting density and size of potato seed-mini tubers on their yielding capacity. Acta Hort., 462: 943-950.

19 EARO 2004. The potential of potato as a world food. In: Proc. Research for the Potato in the year 2004. International Potato Center, Lima, and Peru.pp.

20 Tai, G., Misener, G., Allaby, E., and McMillan, L. (1985). Grav-o-tater: a computer apparatus for measuring specific gravity. American Potato Journal 62, 403-408.

21 Tsegaw, T. (2007). Response of potato to paclobutrazol and manipulation of reproductive growth under tropical conditions, University of Pretoria.

22 El-Latif, K. A., Osman, E., Abdullah, R., and El Kader, N. A. (2011). Response of potato plants to potassium fertilizer rates and soil moisture deficit. Adv. Appl. Sci. Res 2, 388-397. 